\title{
Translating Cats and Cowards
}

Adriana X. Jacobs

1.

On October 8, 2016, a month before the 2016 U.S. presidential elections, The Washington Post published a leaked 2005 Access Hollywood recording that featured sexist remarks made by the then-Republican presidential nominee, Donald J. Trump (Fahrenthold). Although he had a welltracked record of deploying derogatory, objectifying and sexist language, what made this recording remarkable was Trump's specific choice of words. While waiting in a trailer to greet the actress Arianne Zucker on the set of her soap opera Days of Our Lives, Trump boasted to the show's host Billy Bush that as a famous and wealthy man he enjoyed great freedom to make unfettered sexual advances towards women. "Grab 'em by the pussy. You can do anything," he said, and then walked out and greeted Zucker, pulling her toward him as he shook her hand.

\section{2.}

Like most slang, the word pussy has a rich and complicated etymology in the English language. There are records of its use in the sixteenth century where it served as a term of endearment or euphemism for a young girl, a diminutive form of puss, which also referred to a cat or rabbit. By the late nineteenth century, it became synonymous with the female vagina, with some speculation among linguists that this use derives from Old Norse puss, pouch, though how much of this amounts to backtracking is unclear. But the relation to the feline puss overlaps with this meaning, a shared texture that may account as well for the naming of the pussy willow tree. But alongside this history, the word pussy came to apply to men, and specifically to cowards. In fact, at a rally in early February 2016, Trump invoked this meaning when he referred to Senator Ted Cruz as a pussy, though he later claimed that he was echoing what someone in the crowd was 
yelling, "like a retweet," he said (Crocker). He insisted that he himself would never use such a word.

3.

These overlapping meanings of pussy--cats and cowards, vaginas and pouches--lend the word the status of a double entendre, a linguistic wink. This kind of language has long presented a challenge for translators, as Roman Jakobson noted. With the double entendre meanings are so "entangled," as he put it, that the only kind of translation possible was "creative transposition" (Jakobson 118). But when Trump uttered these words in October 2016, the semantic field he was invoking was clear, and we had the example of February 2016 to corroborate this. There was no equivocation.

4.

Understandably, given the stakes of this election, "grab "em by the pussy" circulated widely through the international media, where this expression underwent a range of translations. And as was the case for the English, translating Trump's language into another tested and exposed the borders of what is permissible and appropriate speech in other languages and cultural contexts. While major French, Spanish and German news outlets offered comparable translations of "pussy" in their account of this incident, Israel's main daily paper Haaretz settled on the translation that the Hebrew press would use, with slight modifications, when reporting on this incident, tefos otan be-eivar minan (seize/grab them [fem.] by their [fem.] sex organ) (NYT/Haaretz). In an op-ed on the translation of the term in the Hebrew press, Noga Cohen described this option as "sterile, almost medical" (Cohen). In Haaretz, the Hebrew translation followed the English, where the word pussy appeared without emendation. 
The Hebrew is both a translation and not a translation of the English; it deliberately obfuscates its relation to the English, opting instead for a polite translation that keeps a respectable distance from the original and not because Hebrew lacks a comparable term. On the contrary, Hebrew has kus, an Arabic loanword (like much of Israeli Hebrew slang), but also one to which other relations have been attributed, like the Hebrew words kos, cup, and kis, pocket. If you copy "grab them by the pussy" into Google Translate, the Hebrew translation approximates the Haaretz version, litfos otam 'al yadei ha-kus, to grab them [masc.] by the cunt/pussy. Google Translate takes its cue from available translations, arriving at its solution through consensus. It is not able (yet) to gauge what is appropriate or inappropriate language use, and so it cannot resort to alternative translation strategies (e.g., glossing, circumlocution, paraphrase, omission) when faced with this sort of language. It translates directly and unsentimentally, but its misreading of them, which it renders in the masculine form, could be construed as a felicitous rebuke of the toxic masculinity our president embodies. In this translation, Trump's pussy comes back to grab him.

5.

By restricting the ways in which Trump's language is allowed to circulate through Hebrew, Trump's words are contained, like a contagion that must be quarantined, remaining untranslated in order to reduce the risk of infection and epidemic. Translating this language hazards violating the social norms of a target language and culture, which may have accounted for the refusal on the part of the Hebrew press to translate this language explicitly and directly. ${ }^{i}$ And yet, it may be helpful here to think about Johannes Goransson's critique of still pervasive translation norms in contemporary U.S. poetry, where translation is too often perceived as a threat or bad influence 
(Göransson, "Transgressive Circulation"). In this context, the preferred translation is the one that keeps us intact, clean and undamaged. But this containment also echoes the troubling ways in which Trump and his defenders attempted to contain the scandal, locating these words in the closed, private context of the "locker room" (Smothers). Taken out of this context, into the public sphere on the eve of a contentious election, gave this language a transgressive charge. But the "polite" translation (unwittingly?) colludes with the locker room by insisting that we separate these spheres--the private and the public, the inside and the outside, Trump and ourselves. Locker rooms, after all, can be wiped clean, disinfected. Even The Washington Post did not see fit to print the word and instead opted to remove some of its letters, replacing them with three dashes, as if swiping the word clean.

6. In her essay "The Traffic in Meaning: Translation, Contagion, Infiltration," Mary Louise Pratt calls for a translation practice that makes what is to be translated "comprehensible" (Pratt 29). Translation must allow for connection and interference between source and target cultures and languages. "The translator is always already in some way connected to the imaginative production to be translated," she argues, "some relation across (historical or cultural) distance has brought the original into the translator's purview, into the space of the translator's desire" (Pratt 30). The Hebrew translation disavows this desire, the possibility that such intentions are possible in Hebrew. Its proper translation of pussy is an act of disassociation, a way of expelling Trump's use of this word from the cultural space of the translator, from the Hebrew language itself. Instead, pussy remains across the linguistic border, an outlier, a foreigner, an aberration. Untranslatable. 
7.

The translatability of pussy is not so much at issue here as the urgency that it must be translated. Nevertheless, translatability is a practical matter when it concerns Trump's language. The etymology of pussy that I have offered is a tactic often used by translators to get a sense of a word's range, the number of options available in translation. Translation acknowledges this multiplicity at the same that it sets about orienting itself in the semantic field of a word. The coordinates are not always precise, but translation will get you somewhere. A word may have many sides, but a translator knows the difference between a vagina and a coward. ${ }^{\text {ii }}$ Trump knows the difference too. Trump has proven adept at skirting accountability through his mishmash English, through linguistic strategies of error, evasion, and imprecision. Trump may not feel accountable for anything he says (it's just a retweet), but translating him presents a crucial opportunity to make him accountable. When translating Trump, we must grab his words even if doing so means getting scratched in the process.

\section{Works Cited}

Cohen, Noga. “Kashe lishmo‘a, kal lehit'arev,” Mako (October 12 ,2016), http://www.mako.co.il/women-fitness/feminism/Article-3e16a744a2db751006.htm

Crocker, Lizzy, 'How 'P*ssy' Got Its Power, The Daily Beast (February 2, 2016), www.thedailybeast.com/how-pssy-got-its-power.

Fahrenthold, David A., “Trump Recorded Having Extremely Lewd Conversation about Women in 2005," The Washington Post (October 8, 2016), www.wapo.st/2dSXbkQ.

Göransson, Johannes, ““Transgressive Circulation’: Translation and the Threat of Foreign 
Influence," Cordite Poetry Review (November 1, 2016):

www.cordite.org.au/essays/transgressive-circulation.

Jakobson, Roman, "On the Linguistic Aspects of Translation" (1959), in The Translation Studies Reader, ed. Lawrence Venuti (London: Routledge-Taylor \& Francis, 2000), 113-118.

Juez, Beatriz, "Donald Trump, en un vídeo de 2005: "Una estrella puede hacer cualquier cosa con las mujeres, lo que sea," El Mundo (October 8, 2016), www.elmundo.es/internacional/2016/10/08/57f81dc5268e3e36658b45ea.html.

Pratt, Mary Louise, "The Traffic in Meaning: Translation, Contagion, Infiltration," Profession (2002): 25-36.

New York Times/Haaretz, "Trump be-haklata mi-2005: ke-she-ata kokhav, ata yekhol le'asot lenashim ha-kol," Haaretz (October 8, 2016), www.haaretz.co.il/news/world/america/uselection-2016/1.3089757.

Smothers, Hannah, “Donald Trump's ‘Locker Room Banter’ Is Not Just Harmless Guy Talk,” Cosmopolitan (October 11, 2016), www.cosmopolitan.com/politics/a5265013/lockerroom-talk-donald-trump.

\section{Bio:}

Adriana X. Jacobs is Associate Professor of Modern Hebrew Literature at Oxford University and Fellow of the Oxford Centre for Hebrew and Jewish Studies. She is also a convenor of the research program Oxford Comparative Criticism and Translation. Her monograph Strange Cocktail: Translation and the Making of Modern Hebrew Poetry is forthcoming from the University of Michigan Press. 
${ }^{\mathrm{i}}$ Arabic-language media outlets also declined a more precise translation, employing strategies comparable to the Hebrew.

ii Castilian Spanish, for example, had an almost perfect counterpart in coño, which is both pussy and coward/fool (Juez). 